\title{
Hydration Status and Liver Function of Young Men Before and After Ramadan Fasting
}

\author{
Nur Susan Iriyanti Ibrahim ${ }^{1 *}$, Hardinsyah ${ }^{1}$, Budi Setiawan ${ }^{1}$ \\ ${ }^{1}$ Department of Community Nutrition, Faculty of Human Ecology, Bogor Agricultural University, \\ Bogor 16680, Indonesia
}

\begin{abstract}
The objective of this study was to identify and analyse the hydration status and liver function of young men before and during Ramadan fasting (RF). The study design was a prospective cohort into $1^{\text {st }}$ period (one week before fasting) and $2^{\text {nd }}$ period (the last ten days of fasting). The subjects were 18 healthy young men (19-30 years old). Data on dietary intake were collected using food record $3 \times 24 \mathrm{~h}$, body composition were collected using bioelectrical impedance analyser (BIA), hydration status, and liver function data were measured trough urine and blood sample. This study showed significant differences in body weight, fat body mass, body mass index (BMI), body water, intake of energy, protein, fat, carbohydrate, and water, hydration status (serum osmolality and urine density), and liver function (SGOT and SGPT levels) before and during RF $(p<0.05)$. There were significant correlation between fasting status and SGPT levels $(\mathrm{p}<0.05)$. The study concluded that Ramadan fasting has a positive effect to control body weight and improve liver function measured by SGOT and SGPT levels.
\end{abstract}

Keywords: hydration status, liver function, Ramadan fasting, young men

\section{INTRODUCTION}

More than $60 \%$ of the human body consists of water (Buyckx 2007). Water is an essential nutrients which has an important function for physiological and biochemical metabolism. Water function as a transport substance, metabolic heat absorbent, blood volume circulation maintainer, and as a detoxification agent to remove metabolic toxin in the body. Trial in animal studies have shown that the hydration status in the cell have a pivotal role in cell functions, hormones, oxidative stress, and nutrition which then can affect the metabolism and gen expressions. Long-term dehydration without proper treatment may trigger metabolism malfunctions manifest in the body biomarkers (Firmansyah 2015).

Water intake is influenced by many factors such as age, genetics, gender, thirst mechanism, water availability, and sociocultural as well as religious factors (Contento 2011). Ramadan is a holy month in which Muslims have to restrict eating and drinking during the fasting period from dawn to dusk (Alinezhad \& Salehi 2016).

Mohamed et al. (2013) stated that Ramadan fasting (RF) may modifies diet in many ways such as trough changes in the feeding frequency, selection of food type, food preparation, and eating habits. There is a higher risk for dehydration for Muslims who conducted this RF due to the restriction for consumption of all types of foods and beverages (fluid) for about 12 hours (Trepanowski \& Bloomer 2010).

The Indonesian Regional Hydration Research Study (THIRST) shows that even in nor- mal conditions (not fasting), $44.5 \%$ of Indonesian adult subjects (25-55 years old) from two different ecological region (highlands and lowlands) already suffered from mild dehydration (Gustam et al. 2012). Recent study on hydration status during RF conducted by Hardinsyah et al. (2017b) has shown that the subjects only drank $2042.90 \pm 452.61 \mathrm{ml} /$ day of total water, or $91 \%$ of their water requirement. This study also found that in late afternoon near the time of iftar, the body actually has the highest water requirement (Hardinsyah et al. 2017b).

While in the other hand, some studies has found that RF have benefited the physical and mental health. Fasting is described to have a positive effect for lipid profile and other haematological parameters (Fararjeh et al. 2012). RF also shown to lower the level of anxiety, frustration, and depression (Mousavi et al. 2014). Another benefit of RF is as a natural detoxification process which largely happened in the liver. Liver has a capability to clean the blood from toxins, bacteria, viruses, parasites, tumour cells, and foreign particles that may harm the body (Hardinsyah 2011). Liver function during RF is shown to be getting better. Levels of serum glutamic oxaloacetic transaminase (SGOT) and serum glutamate pyruvate transaminase (SGPT) was lower after RF (Wahjoetomo 1999 in Hardinsyah 2011). Therefore, this study aimed to identify and analyse the nutritional status, body composition, food intake, fluid consumption, hydration status, and liver function of the subjects before and during RF. Further, this study also aimed to analyse the correlation between RF to hydration status

"Corresponding Author: Tel:+6281289491768, email: susangm47@gmail.com 
and liver function, and of hydration status to liver function.

\section{METHODS}

\section{Design, location, and time}

The study design was a prospective, divided into two periods, $1^{\text {st }}$ period was one week before $\mathrm{RF}$ and $2^{\text {nd }}$ period was the last 10 days of RF. This study was conducted in Bogor Agricultural University (BAU) from May to July 2016. This study was a joint research of "Water Intake and Hydration Status of Adults Before and During Ramadan Fasting" chaired by Prof. Dr. Ir. Hardinsyah, MS.

\section{Materials and tools}

Subjects chosen for the study were young male adult because they were more likely to finish the RF (28-30 days) without any missed time due to menstruation women. They were young student of BAU. The inclusion criteria for this study were male, 19-30 years old, BMI 18.5-27 $\mathrm{kg} / \mathrm{m}^{2}$, in healthy condition, non-smoker, willing to be a subject and fully participate in this study and willing to approve the informed consent. The exclusion criteria were subjects with a certain health conditions which can impede the commitment to finish the full RF.

\section{Data collection}

The primary data collected at each periods of the study were 1) dietary intake, collected using food record $3 \times 24$ hours; 2) nutrition status, measured using CAMRY EB9003 for body weight and stature meter for body height, and bioelectrical impedance analyser (BIA) for body composition; 3) hydration status, measured using serum osmolality and urine specific gravity (USG); 4) liver function, measured using level of SGOT, SGPT, albumin serum, and bilirubin urine. The ethical clearance letter for the study is issued by the Faculty of Medicine University of Indonesia (number of 440/UN2.F1/ETIK/2016).

Body weight and height measured twice or more until the measurement was consistent. While measurement of other data was only carried in once. Body height was measured only in $1^{\text {st }}$ periods of this study with the assumption that no significant changes in height occurred between the $1^{\text {st }}$ and $2^{\text {nd }}$ period. The types of liver function biomarkers used in this study were 1) transport function of the organic substance test and drug metabolism using the bilirubin urine test, 2) cell or liver tissue damage test using SGOT (an enzyme that found more in mitochondria and cytoplasm) and SGPT levels test (an enzyme that only found in cytoplasm), and 3) biosynthesis function test using albumin serum test. Urine sample was collected in the day time (12.00-13.00) and in the afternoon (16.00-17.00). It was collected using sealed glass bottle about $25-30 \mathrm{ml}$ and then was analysed in BAU urine analysis laboratory using urine chemistry analyser (DUS R-300).

Blood sample was collected in the morning (08.00-10.00) at the $1^{\text {st }}$ periods of this study and after iftar with drinking water at the $2^{\text {nd }}$ periods of this study. Blood was drawn by trained medical personnel, about $5 \mathrm{ml}$ using syringe then blood centrifuged to separate the plasma and serum.

Serum sample was put into the micro tube and cooler box with maximum temperature of $7^{\circ} \mathrm{C}$, then it analysed at Amerind Bio-Clinic (ABC) Jakarta laboratory and laboratory clinic of PKU Muhammadiyah Bogor. Sample was analysed using osmometer automatic to measure serum osmolality data. While Photometric UV-test was done for measuring the SGOT, SGPT, and albumin serum level.

\section{Data Analysis}

Data were processed using Microsoft Excel 2010 and analysed using SPSS 16.0 version. Difference test between variables before and during RF was conducted using paired t-test and Wilcoxon. Regression test was done using multiple linear regression.

\section{RESULTS AND DISCUSSION}

\section{Characteristic of subjects}

Subjects were 18 men with the average age of 22.0 2.4 years old and all subjects were a BAU student $(100 \%), 72.2 \%$ were undergraduate student and $27.8 \%$ were postgraduate student. The average allowance were $1,240,000 \pm 1,060,000$ (IDR) per month. $61.1 \%$ of subjects allocated more than 450,000 (IDR) for foods and $72.2 \%$ allocated less than 152,000 (IDR) for beverages per month.

\section{Nutrition status, body composition, and nut- rition intake before and during Ramadan fast- ing}

The result found that body weight, total body fat, visceral fat, total body water, and BMI during RF were significantly decreasing $(p<0.05)$ (Table 1). This result was in line with study by Syam (2016). Decreasing of body weight was caused by decreasing of body water and body fat percentage during fasting. Reducing of body water caused by body water alteration during RF. These may increase risk of dehydration (Mazidi et al. 2014).

RF has shown to decrease carbohydrate intake and carbohydrate oxidation and thus increase the fat oxidation. The restriction of nutrition intake induced the body to use stored energy (glycogen) and fat deposits as energy resources during RF. Fat percentage decreased was the visceral fat or fat around the abdominal cavity (tummy fat). These fat has the highest rate of lipolysis 
Table 1. The distribution of subjects based on nutrition status, body composition, and nutrition intake before and during RF

\begin{tabular}{|c|c|c|c|c|}
\hline \multirow{2}{*}{ Variables } & Before RF $(n=18)$ & During RF (n=18) & \multirow{2}{*}{ Delta } & \multirow{2}{*}{$\mathrm{p}$} \\
\hline & Median \pm SD & Median \pm SD & & \\
\hline Body height $(\mathrm{cm})$ & $166.4 \pm 4.9$ & $166.4 \pm 4.9$ & 0 & 1.000 \\
\hline Body weight (kg) & $61.4 \pm 6.9$ & $60.4 \pm 7.3$ & -1.1 & $0.001 *$ \\
\hline Body fat $(\mathrm{kg})$ & $13.1 \pm 4.6$ & $12.7 \pm 4.7$ & -0.4 & $0.046^{*}$ \\
\hline Visceral fat $(\mathrm{kg})$ & $5.6 \pm 2.2$ & $5.20 \pm 22.1$ & -0.4 & $0.002 *$ \\
\hline Total body water $(\mathrm{kg})$ & $35.5 \pm 3.0$ & $34.8 \pm 2.9$ & -0.7 & $0.001 *$ \\
\hline BMI $\left(\mathrm{kg} / \mathrm{m}^{2}\right)$ & $22.3 \pm 2.2$ & $21.8 \pm 2.3$ & -0.5 & $0.000^{*}$ \\
\hline \multicolumn{5}{|l|}{ Intake } \\
\hline Energy (kcal) & $1,950 \pm 503$ & $1,709 \pm 367$ & -240 & $0.019 *$ \\
\hline Protein (g) & $63.0 \pm 15.3$ & $54.3 \pm 14.9$ & -8.7 & $0.005^{*}$ \\
\hline Fat $(\mathrm{g})$ & $64.5 \pm 17.6$ & $48.4 \pm 16.9$ & -16.2 & $0.000 *$ \\
\hline Carbohydrate (g) & $288.8 \pm 82.3$ & $262.3 \pm 71.4$ & -26.5 & $0.024 *$ \\
\hline
\end{tabular}

during fat oxidation (Sinaiko 2007). Increase in fat oxidation occurs due to the decrease of nutrition intake during RF, refer to Table 1.

There is a significant decrease in nutrition intake (energy, protein, fat, and carbohydrate) during RF $(\mathrm{p}<0.05)$. Hardinsyah (2011) stated that in general the amount of calories which goes into the body was in limited amount during fasting. People only eat $75-80 \%$ from the daily calorie intake, therefore after RF the body weight decrease in about 5-10\%. Lower nutrition intake during RF happened because of the limited time to eat and choices of types of food. Study by Unalacak et al. (2010) showed that restriction of nutrition intake was caused by the changing of eating pattern, from 3 times per day to 2 times per day, thus reduce the total energy intake.

Water intake, water intake level, and hydration status before and during Ramadan fasting

There was a significant differences of water intake and water intake levels before and during RF $(p<0.05)$ (Table 2). Most of the subjects have low water intake levels $(<90 \%)$ during fasting. These caused by limitation of all types' food and beverages during fasting about more than 12 hours (Trepanowski \& Bloomer 2010). Al-Arouj et al. (2010) recommended to increase water intake during no fasting time and sahoor time. People should have enough drink at the end of sahoor, before fasting time and when iftar time in order to prevent the risk of dehydration.

Hydration status in this study was measured using 2 methods, serum osmolality and USG which were gold standard measurements for hydration status using blood and urine samples. There was significant decrease in serum osmolality level during fasting $(\mathrm{p}<0.05)$. The majority of subjects had normal serum osmolality levels (euhydration). These condition occur due to the homeostasis mechanism during fasting, so that serum osmolality is able to be maintained in normal levels. Hosseini et al. (2013); Dikme and Dikme (2016) pointed that there was no signifi- cant differences in osmolality serum before and during RF. Unchanging serum osmolality may be caused by normal levels of plasma sodium or the balance condition of fluid and sodium. Increasing of serum osmolality can occur due to the hypernatremia or excess of sodium intake (Kuwabara et al. 2017).

Hydration status based on USG level shows that before and during RF all subject were suffering from dehydration $(100 \%)$. These because the subjects had the same water intake ha-bits before and during RF. These result was in line with Hardinsyah et al. (2017b), that all subjects were suffering from dehydration and was worse during fasting, especially in the afternoon near iftar time based on the USG levels. There was no positive correlation between serum osmolality and USG. Less subjects were categorized as having dehydration based on osmolality levels compared to the USG levels. These can be explained by the homeostasis mechanism in body.

Changing of osmolality activates the osmoreceptor, so that can increase the antidiuretic hormone (ADH) and stimulate the thirsty mechanism. Increasing of osmolality can causes dehydration and become more severe without immediate fluid consumption during fasting. These induced the kidney to reabsorb water for maintenance and fluid balancing in the body, so the urine will decrease in volume and be more concentrated and the body water will at normal level (Hardinsyah et al. 2017a).

The present of this mechanism was confirmed by data on subject's dehydration symptoms of this study. More subjects claimed decrease in urine volume and more concentrated urine during the RF. In addition, self-urine check cards result also showed that more subject had more concentrated urine colour during fasting.

\section{Liver function before and during Ramadan fasting}

Table 3 shows significant decrease in SGOT and SGPT level during fasting $(\mathrm{p}<0.05)$. 
Table 2. The distribution of subjects based on water intake, water intake levels, and hydration status before and during Ramadan fasting

\begin{tabular}{|c|c|c|c|}
\hline Variables & Before fasting & During fasting & $\mathrm{p}$ \\
\hline Water intake $($ mean \pm SD) & $2571.7 \pm 373.7$ & $2305.5 \pm 337.3$ & $0.000 *$ \\
\hline Water requirement $($ mean $\pm \mathrm{SD})$ & $2701.4 \pm 239.2$ & $2503.1 \pm 231.8$ & \\
\hline Water intake level $($ mean \pm SD) & $95.2 \pm 15.6$ & $85.4 \pm 14.6$ & $0.000 *$ \\
\hline Severe $(<90 \%)(\mathrm{n}(\%))$ & $8(44.4 \%)$ & $12(66.7 \%)$ & \\
\hline Normal $(\geq 90 \%)(\mathrm{n}(\%))$ & $10(55.6 \%)$ & $6(33.3 \%)$ & \\
\hline Total $(\mathrm{n}(\%))$ & $18(100 \%)$ & $18(100 \%)$ & \\
\hline Serum osmolality $($ mean \pm SD) & $319 \pm 7.0$ & $315 \pm 4.9$ & $0.010^{* *}$ \\
\hline Euhydration $\left(<320 \mathrm{mlosmol} / \mathrm{kgH}_{2} \mathrm{O}\right)(\mathrm{n}(\%))$ & $12(66.7)$ & $17(94.4)$ & \\
\hline Dehydration $\left(\geq 320 \mathrm{mlosmol} / \mathrm{kgH}_{2} \mathrm{O}\right)(\mathrm{n}(\%))$ & $6(33.3)$ & $1(5.6)$ & \\
\hline Total $(\mathrm{n}(\%))$ & $18(100.0)$ & $18(100.0)$ & \\
\hline USG (mean \pm SD) & $1.016 \pm 0.00$ & $1.022 \pm 0.00$ & $0.001 * *$ \\
\hline Euhydration $(\mathrm{USG}<1.015 \mathrm{~g} / \mathrm{mL})(\mathrm{n}(\%))$ & $0(0.0)$ & $0(0.0)$ & \\
\hline Dehydration (USG $\geq 1.015 \mathrm{~g} / \mathrm{mL})(\mathrm{n}(\%))$ & $18(0.0)$ & $18(0.0)$ & \\
\hline Total $(\mathrm{n}(\%))$ & $18(100.0)$ & $18(100.0)$ & \\
\hline
\end{tabular}

* Significantly paired t-test in $\left.\mathrm{p}<0.05,{ }^{* *}\right)$ Significantly Wilcoxon test in $\mathrm{p}<0.05$

These results indicated that the liver was working more lightly and had lower risk to cell damage during fasting. Study by Wahjoetomo (1994) in Hardinsyah (2011) and Nasiri et al. (2016) also found that SGOT and SGPT serum levels during fasting were lower than before fasting.

Some factors that may increase the SGPT levels are excess of fat intake, alcohol consumption, smoking habits, and free radicals exposed (Hardinsyah 2011). Subject in this study were non-smokers and consume no alcohol. Subject's fat consumption was not in excess, it was $\leq 91$ $\mathrm{g}$ based on RDA (2013). So the decreasing of SGPT levels in this study was explained by the fasting done by subject during the Ramadan holy month. Exposure of free radicals in this study not only from cigarette smoke but also from food and energy metabolism in the body. Food like carbohydrate, fat, and protein sources will be breakdown to form energy, so it needs large amount of oxygen capacity. Increasing oxygen will lead to production of free radicals in the body. When the metabolism is increasing, detoxification organ performed in heavier task (Hardinsyah 2011).

Carbohydrate, fat, and protein intake before and during RF in this study were significantly different and decrease during fasting, so the free radicals exposure and toxin from food were low. Therefore, the optimum cell regeneration process will happen and the detoxification organ carries lighter task (Hardinsyah 2011). These process was characterized by the decrease in SGOT and SGPT levels in the liver tissue (Table 3).

SGOT is an enzyme which helps the gluconeogenesis process in the mitochondria. When the carbohydrate intake is low during fasting, the body will breakdown the energy storage (fat) in the body to produce the glucose as an energy source for activities. As a result the SGOT enzyme is required in optimum amount as a catalyst. During fasting the breakdown of fat to energy (gluconeogenesis) still under control, so the secretion of SGOT was not too high like in normal time. It means that the liver was working lighter through the recycle of the energy deposits in the body during fasting (Thapa \& Walia 2007).

SGPT is an enzyme which produced by liver tissue and has higher activity in the liver. The significant decrease of SGPT in this study occurred due to the lowering of glycolysis process in the cytosol, this was caused by restriction of carbohydrate intake during fasting and the body uses glycogen in limited quantities for glycolysis. Cytosol is the site of glycolysis and SGPT is the key enzyme. So that when intake of carbohydrate was restricted and so was the glycolysis, the SGPT enzyme excretion would also be going down (Thapa \& Walia 2007).

Table 3 also shows that there is a tendency of decline in albumin serum level, but no significant differences $(p>0.05)$. These results were in line with study by Mohammed (2011) and Kamal et al. (2012) who found that there was no significant differences between albumin level before and during RF. Decreasing of albumin level was suspected by proteolysis from gluconeogenesis. There no decrease of body muscle percentage, but only decreasing in energy resource and body fat percentage in the body (Syam 2016).

The other test of liver function was bilirubin urine. The result showed that there was no bilirubin found in the most of subject's urine. Study by Mohammed (2011) also found that there was no significant differences before, during, and after RF. The existence of bilirubin content in subject's urine indicated the damage of liver tissue or increasing of haemoglobin breakdown.

\section{The regression of fasting status and hydration status to liver function}

Table 4 shows the multiple linear regression analysis was used to analyse the correlation of fasting status and hydration status (serum osmolality and USG) to liver function (SGPT 
Table 3. Liver function (mean \pm SD) before and during RF

\begin{tabular}{lcccc}
\hline \multicolumn{1}{c}{ Variable } & Before fasting $(\mathrm{n}=18)$ & During fasting $(\mathrm{n}=18)$ & Delta & $\mathrm{p}$ \\
\hline SGOT (U/L) & $21.3 \pm 5.8$ & $18.9 \pm 4.7$ & -2.4 & $0.000^{*}$ \\
SGPT (U/L) & $25.8 \pm 6.7$ & $21.2 \pm 6.2$ & -4.7 & $0.000^{*}$ \\
Albumin (g/dl) & $4.2 \pm 0.2$ & $4.1 \pm 0.1$ & -0.02 & 0.717 \\
Bilirubin $\mathrm{n}(\%)$ & & & & \\
$\quad$ Negative & $17(94.4)$ & $17(94.4)$ & & \\
$\quad$ Positive & $1(5.6)$ & $1(5.6)$ & & \\
\hline * & & &
\end{tabular}

*) Significantly paired t-test in $\mathrm{p}<0.05$

Table 4. The regression of fasting status and hydration status to liver function (SGPT level)

\begin{tabular}{|c|c|c|c|c|c|c|}
\hline \multirow{2}{*}{ Model } & & $\begin{array}{l}\text { Unstandardized } \\
\text { Coefficients }\end{array}$ & & $\begin{array}{l}\text { Standardized } \\
\text { Coefficients }\end{array}$ & \multirow[t]{2}{*}{$\mathrm{T}$} & \multirow{2}{*}{$\mathrm{p}$} \\
\hline & & B & Std. Error & Beta & & \\
\hline 1 & $\begin{array}{l}\text { (Constant) } \\
\text { Fasting status } \\
\text { Serum osmolality }\end{array}$ & $\begin{array}{c}-83.419 \\
-2.838 \\
.343\end{array}$ & $\begin{array}{l}54.547 \\
2.084 \\
0.171\end{array}$ & $\begin{array}{c}-0.221 \\
0.326\end{array}$ & $\begin{array}{c}-1.529 \\
-1.362 \\
2.004\end{array}$ & $\begin{array}{l}0.136 \\
0.183 \\
0.053\end{array}$ \\
\hline 2 & $\begin{array}{l}\text { (Constant) } \\
\text { Fasting status } \\
\text { USG }\end{array}$ & $\begin{array}{c}-491.394 \\
-6.826 \\
508.609\end{array}$ & $\begin{array}{c}302.720 \\
2.620 \\
297.673\end{array}$ & $\begin{array}{c}-0.532 \\
0.349\end{array}$ & $\begin{array}{c}-1.623 \\
-2.605 \\
1.709\end{array}$ & $\begin{array}{l}0.114 \\
0.014^{*} \\
0.097\end{array}$ \\
\hline
\end{tabular}

level). The result shows that fasting status effect SGPT level more compared to hydration status $(p<0.05)$. Hydration status in this study was not affecting the SGPT level, because water a direct antitoxins in the body. Water may speed up toxin clearance by functioning as solvent therefore water can help in filtration and excretion of body fluid by kidney resulted in urine secretion (Hardinsyah 2011).

SGPT level was significantly affected by fasting status through the nutrients metabolism during fasting. The decrease in carbohydrate intake during fasting because of the limited time for eating lowers the SGPT enzyme secretion (Thapa \& Walia 2007) (Trabelsi et al. 2011).

\section{CONCLUSION}

Ramadan fasting had positive effect for decreasing of BMI through the lowering of the body fat percentage because of energy, protein, fat, and carbohydrates intake are restricted. Most of subjects had severe hydration status (dehydration) during RF. The bad drinking habits before and during fasting explained this result. Another benefit of RF is that the liver function became better. It was characterized by the lowering of SGOT and SGPT levels. The benefits of RF appeared when the nutrients intake was balance each day.

The limitations of this study were the small number of subjects, done without control subjects and the hydration status was measured only in a week before fasting and the last 10 days of fasting. Therefore, future research should look into fluctuation in hydration status during RF, and the study must conducted in large number of subjects and in various subjects with different hydration status.

\section{REFERENCES}

Al-Arouj et al. 2010. Recomendations for management of diabetes during Ramadan. Diabetes Care 33(8):1895-1902.

Alinezhad NM, Salehi M. 2016. Effect of Ramadan fasting on blood pressure in hypertensive patients: a systematic review. J Fasting Health 4(1):17-21.

Buyckx ME. 2007. Hydration and health promotion: a brief introduction. J Am Coll Nutr 5(26):533S-534S.

Contento IR. 2011. Nutrition Education Linking Research, Theory, and Practice. Canada: Jones and Bartlett Publishers International.

Dikme O, Dikme O. 2016. Ramadan fasting and its influence on serum osmolality in emergency patients. J Emerg Med Critical Care 2(1): 1-4.

Fararjeh MA, Bustanji YK, Mohammad MK, Saleme ML. 2012. Intermittent fasting during Ramadan attenuates proinflammatory cytokines and immune cells in healthy subjects. Nutr res 3(2):947-955.

Firmansyah MA. 2015. Pengaruh puasa Ramadan pada beberapa kondisi kesehatan. CKD 42(7):510-514.

Gustam, Briawan, H ardinsyah. 2012. Risk factors of dehydration in indonesian adolescents and adults. J Gizi Pangan 8(1):1-9. 
Hardinsyah, Santoso BI, Siregar P, Pardede SO. $2017 \mathrm{a}$. Water for Health $3^{\text {th }}$ Edition. Jakarta: Centra Communications.

Hardinsyah, Mawadaturrohmah N, Abinowo KP, Baliwati YF. 2017b. Hydration status and water intake of women during and after Ramadan fasting. Malays J Nutr (supplement) 23(1):S63-S70.

Hardinsyah. 2011. Detox While Fasting. Jakarta: PT. Gramedia.

Hosseini SRA, Sardar MA, Hejazi K, Farahati S. 2013. The effect of Ramadhan fasting and physical activity on body composition, serum osmolality levels and some parameters of electrolytes in female. Int J Endocrinol Metab 2(2):88-94.

Kamal S, Ahmad QS, Sayedda K, Haque M. 2012. Effect of islamic fasting on lipid profile, total protein and albumin on healthy muslim man subjects of shri ram murti smarak institute of medical sciences, bareilly, uttar pradesh. National journal of medical research 2(4):407-410.

Kuwabara et al. 2017. Increased serum sodium and serum osmolarity are independent risk factors for developing chronic kidney disease; 5 year cohort study. pone. Doi:10.1371/journal.pone.0169137.

Mazidi M, Karimi E, Rezaee P, Nematy M, Salehi M. 2014. The effect of Ramadan fasting on body composition. Shiraz E-Med J. Doi:10.17795/sej19733.

Mohamed HJJ, Nazri NH, See-ling L. 2013. Ramadan bazaar and Ramadan buffets: the possible influence on eating behaviour and health among Malaysian muslims. J Fasting Health 1(2):43-45.
Mohammed ZJ. 2011. The influence of Ramadan fasting on some hematological and biochemical parameters in healthy adult mans. Iraqi National J. For Nursing Specialties 24(1):45-51.

Mousavi SA, Rezaei M, Baghni SA, Seifi M. 2014. Effect of fasting on mental health in the general population of Kermanshah, Iran. J Fasting Health 2(2):65-70.

Nasiri J, Kheiri S, Khoshdel A, Boroujeni AJ. 2016. Effect of Ramadan fast on liver function tests. Iran J Med Sci 41(5):459-460.

Sinaiko A. 2007. Obesity, insulin resistance and the metabolic syndrome. J Pediatr 83(1): 3-5.

Syam AF, Sobur CS, Abdullah M, Makmun D. 2016. Ramadan fasting decreases body fat but not protein mass. Int J Endocrinol Metab. Doi: 10.5812/ijem.29687.

Thapa BR, Walia A. 2007. Liver function tests and thei interpretation. Indian $\mathrm{J}$ Pedistr 74(7):663-671.

Trabelsi K, Abed K, Trepanowski JF, Stannard SR, Ghlissi Z, Ghozzi H, Masmoudi L, Jammoussi K, Hakim A. 2011. Effects of Ramadan fasting on biochemical and anthropometric parameters in physically active men. Asian J Sports Med 2(3):134144.

Trepanowski JF, Bloomer RJ. 2010. The impact of religious fasting on human health. Nutr $\mathrm{J}$ 9(57):2-5.

Unalacak M, Kara, Baltaci D, Erdem O, Bucaktepe GE. 2010. Effects of Ramadan fasting on biochemical and hematological parameters and cytokines in healthy and obese individuals, metabolic syndrome and related disorders. Mary Ann Liebert 9(2):157-161. 